\title{
Erratum to: Factors influencing the uptake of a mechatronics curriculum initiative in five Australian secondary schools
}

\author{
Howard Nicholas • Wan Ng
}

Published online: 14 February 2011

(C) Springer Science+Business Media B.V. 2011

\section{Erratum to: Int J Technol Des Educ DOI 10.1007/s10798-010-9138-0}

Since submission of the article, my affiliation has changed to the University of New South Wales, Australia, and that the University of New South Wales should be noted as my correct affiliation.

The online version of the original article can be found under doi:10.1007/s10798-010-9138-0.

H. Nicholas $(\bowtie)$

Faculty of Education (Bundoora), La Trobe University, Bundoora, VIC 3086, Australia

e-mail: h.nicholas@1atrobe.edu.au

W. $\mathrm{Ng}$

University of New South Wales, Sydney, NSW 2052, Australia

e-mail:w.ng@latrobe.edu.au;w.ng@unsw.edu.au 